Poznań Studies in Contemporary Linguistics 49(3), 2013, pp. 321-353

(C) Faculty of English, Adam Mickiewicz University, Poznań, Poland

doi:10.1515/psicl-2013-0012

\title{
GERMAN IN SAMOA: HISTORICAL TRACES OF A COLONIAL VARIETY
}

\author{
DORIS STOLBERG \\ Institut für Deutsche Sprache, Mannheim \\ stolberg@ids-mannheim.de
}

\begin{abstract}
During the brief era of German colonialism in the Pacific (1884-1914), German was in contact with a large number of languages, autochthonous as well as colonial ones. This setting led to language contact in which German influenced and was influenced by various languages. In 1900, Western Samoa came under German colonial rule. The German language held a certain prestige there which is mirrored by the numbers of voluntary Samoan learners of German. On the other hand, the preferred use of English, rather than German, by native speakers of German was frequently noted. This paper examines linguistic and metalinguistic data that suggest the historical existence of (the precursor of) a colonial variety of German as spoken in Samoa. This variety seems to have been marked mainly by lexical borrowing from English and Samoan and was, because of these borrowings, not fully comprehensible to Germans who had never encountered the variety or the colonial setting in Samoa. It is discussed whether this variety can be considered a separate variety of German on linguistic grounds.
\end{abstract}

KEYWORDS: Language contact; colonial linguistics; lexical borrowing; Samoan German.

\section{Introduction $^{1}$}

During the fairly brief era of German colonialism in the Pacific, German held a prestigious position as the native language of an exogenic economic and political elite. In this setting, it was in contact with a large number of languages, local as well as colonial ones.

\footnotetext{
${ }^{1}$ I wish to thank two anonymous $P S i C L$ reviewers who provided valuable feedback on an earlier version of this paper. All remaining shortcomings are, of course, my responsibility.
} 
The main focus of this paper is the historical colonial language situation in (German) Samoa. The high prestige German held with the autochthonous Samoan population was reflected by the considerable number of voluntary learners of German (cf. Hiery 2001b; Otto 1989). On the other hand, and primarily with respect to the native speakers of German, there was a tension of power and prestige between German and the other colonial language spoken in Samoa, English. The Samoanische Zeitung (SamZ), a German newspaper in Samoa published in Apia between 1901 and 1914, criticized repeatedly that native speakers of German preferred using English in prestigious settings, independent of their level of competence in this language (e.g., SamZ of 8 July 1911; cf. also Zieschank 1918). In addition, their German was reported to be mixed with English (lexical) elements.

My investigation takes up the question of whether, and if so, to what extent, anecdotal reports about language choice and language usage in the Germancolonial context of Samoa can be supported by further data. Historical written sources are examined in order to judge in which ways the local use of German led to a changed variety in this multilingual and sociolinguistically complex environment. Metalinguistic and linguistic data are analysed and evaluated to assess the extent and type of change found. ${ }^{2}$

It is discussed whether it is appropriate on linguistic grounds to refer to this variety of German as a (contact) variety distinct from other varieties of German, or whether respective reports are based mainly on language-purist intentions, expressing language attitudes rather than reporting linguistic observations. Different factors pertaining to this question are discussed, for example: Did an identifiable speech community of Samoan German exist, or do corresponding reports rather refer to language-mixing idiolects of individual speakers? What do we know about the duration of existence of this (presumed) variety? Does the database provide evidence for a linguistically stable or stabilizing variety (in form of, e.g., recurring lexical borrowings or semantic changes), or does the available evidence rather point in the direction of spontaneous and nonestablished mixing processes?

The paper thus focusses on language contact and its sociolinguistic aspects in a historical setting. Its main goal is to trace contact phenomena distinguishing German as spoken in Samoa from German in Germany, in order to discuss (a) whether they should be considered on-the-spot borrowings or rather estab-

\footnotetext{
${ }^{2}$ This does by no means preclude the possibility that there may be additional data providing information on the (German) language use of, e.g., German speakers of Samoan-German descent. The data investigated here are generally produced by German expatriates; thus, they reflect a specific variety and perspective. This should be kept in mind throughout the paper.
} 
lished loans; and (b) if there is a sufficient number of them to consider this variant an emerging settler variety in its own right.

\section{Historical background}

Between 1884 and 1914, Germany administered a number of colonies in the Pacific. The German government's interest in these dealings was primarily economically and politically driven (cf. Boulleys 1998); a cultural as well as linguistic impact on the local population, however, was considered necessary for economic reasons and desirable from a contemporary moral perspective.

Already from the 17th century onwards, Christian missionaries of diverse confessional, national, and linguistic backgrounds (mainly Spanish, English, Dutch, French, and German) had arrived in what was to become the German colonial area in the Pacific; they had learned local languages and set up churches as well as schools where religious instruction, and often reading and writing, were taught (cf. Garrett 1982). Whaling and trading were early occasions for contact, too, fostering the development of Pidgin English in the Pacific (Tryon and Charpentier 2004; Wurm and Mühlhäusler 1984). In 1857, the first trading station of the German firm Godeffroy in Samoa established trading relations between Germany and Samoa (e.g. DiPaola 2004). A Friendship Treaty between Prussia and Samoa followed in 1879 (DRGBl 1881: 29-34), consolidating favorable trading conditions for Germany in Samoa. In 1900, following the conflict-laden period of a British-German-U.S. American tridominium in Samoa, Western Samoa came under German colonial administration.

With the onset of German colonial administration, a small number of German administrative officials and German settlers moved into the Pacific colonies. While settlers tended to stay for a longer period, administrative staff were usually transferred after a few years. A strong linguistic impact was probably not effected by these two groups: The settlers tended to adjust to local custom and frequently used English or the developing Pidgin English for trading and other interactions, and apparently also among themselves (e.g. SamZ, 28 Feb 1903; 8 July 1911; cf. Hiery 2001b: 215). Administrative officials are reported to have often done the same (ABCFM-3, cf. Engelberg 2006: 15-16; ABCFM$42: 2^{3}$ ). In many places, English had acquired a sound position as a lingua fran-

\footnotetext{
${ }^{3}$ I wish to thank Stefan Engelberg for making available to me archival material from the American Board of Commissioners for Foreign Missions (Boston, USA) and from the National Archives of New Zealand (Wellington, N.Z.).
} 
$c a$ between the local population and the European-origin expatriates, as well as among the expatriates themselves. There were strongly conflicting opinions "at home", that is, in Germany, on whether or not to spread the German language (cf. Engelberg 2006; Friederici 1911; Hiery 2001c; Sembritzki 1913), and throughout Germany's colonial period the so-called Sprachenfrage, the language question, was never ultimately resolved (cf. Engelberg and Stolberg 2012; Stolberg to appear for a discussion of German colonial language policies and their arguable efficacy).

The European community in Samoa consisted mainly of planters, settlers, traders, and businessmen, as well as government officials and administrative staff, mostly men with only a few women among them (Zieschank 1918; Scheurmann 1935). Their numbers were low: Out of a total population of $\mathrm{c}$. 33,000 in Western Samoa at this time (StJbDR, 1910/11: 396; DKAJb 1905: $18 \mathrm{ff}$.), about 600 were expatriates (Hiery 2001a: 653), out of which only 284 were Germans (in 1911). Most expatriates lived on Upolu, the southeastern one of the two main islands of Western Samoa, with a high concentration in and around Apia (the seat of the colonial government and the main trading centre), while Savai'i, the northwestern island, remained rather less influenced by colonists (cf. Flaherty 1932). Thus, the preconditions were favorable for a close-knit community of expatriates that could develop their own speech habits (cf. Zieschank 1918: 51, 116 regarding the close social interactions shortly after 1900).

\section{Sociolinguistic context}

The group of European-origin expatriates is described as a group with close societal ties, European-based structures, and regular interactions at social events (Berger 1923; Scheurmann 1935; Zieschank 1918). The community was small and most members knew each other; unknown arrivals were looked upon with some suspicion (Berger 1932: 10; Scheurmann 1935: 8). Mutual moral judgements are contained in several of the published accounts and were part of this close social network.

\subsection{Languages}

Samoan contact with Germany, and German, started in the mid-19th century, but contact with English occurred earlier and was more persistent. The first 
Christian mission society in Samoa was the English-speaking London Missionary Society (LMS), starting their work there in 1830. When Samoa came under German rule, English was well established as the lingua franca among European-origin expatriates (cf. Mühlhäusler 1984). Various metalinguistic comments in contemporary publications (e.g., travel reports and the SamZ, cf. Section 5 below), support the notion that English was the primary language of the European elite, including expatriate non-native speakers of English. English apparently had a high prestige, and it was lamented that even a rather limited competence of it did not prevent native speakers of German from switching to English as soon as there was even a small number of native speakers of English among them (e.g., SamZ, 28 Feb 1903; SamZ, 26 Jul 1913); a communicative behavior that appears quite appropriate from a pragmatic point of view but undesirable from a colonial nationalist perspective.

German was usually spoken among Germans (if no English speakers were present); occasionally it was used between Samoans and expatriates (Scheurmann 1935: 14). It seems to have held a relatively high prestige for Samoan learners of German (cf. Hiery 2001b), despite the prominent position of English. On the other hand, German native speakers themselves seem to have attached a higher prestige to English than to German (cf. Stolberg 2011). This is reflected in their reported language behavior in official and prestigious settings (e.g. Zieschank 1918; Scheurmann 1935).

Besides the colonial languages English and German, the main languages spoken in Samoa were Samoan, among the local population, and in some settings between Europeans and Samoans; and Pidgin English on the plantations (with and among indentured labourers; maybe to some degree also among domestics, cf. Zieschank 1918: 19).

English was considered to pose the strongest threat for German. This is made explicit in several articles in the SamZ (e.g., SamZ, 8 Jul 1911: 2: "nur von dem Englischen droht uns hier Gefahr" [it is only from English that we are threatened here]). English had been in use in Samoa for several decades more than German and was well established in most business and trading contexts. In contrast to English-speaking mission work, a German-speaking mission was never established (cf. Berger 1923: 117). Business and administrative meetings were often held in English even when the majority of attendants did not have a sufficient command of it and needed a translation into German (Hiery 2001a: 651; Zieschank 1918: 58; cf. the report on the Planters' Union Meeting, SamZ, 28 Feb 1903). 
The language competences and preferred language choices of different speaker groups are summarized by an article in the SamZ, 8 Jul 1911 (p. 1-2) as follows:

Germans: know German and English (the latter sometimes poorly), know some Samoan (only few of them, cf. SamZ, Dec. 7, 1901: 2); use mainly English; increasing competence in (L2) English

Samoans: know Samoan, English, and some German; use Samoan and English; attrition ${ }^{4}$ in (L2) German (due to few opportunities for use)

English (including tourists and short term visitors): know English and a little Samoan; use English

The conclusion drawn is that English is used at most occasions, even by speakers with a medium to low competence; and there seems to be little opportunity to apply German on a daily basis, even for those (Samoan) learners of German who have (or had) a good command of it.

In this setting, German was subject to various kinds of contact influence, in particular from English. The multilingual setting caused a situation in which at least English and German were activated ${ }^{5}$ in the speakers' minds for many native speakers of German in several contexts, possibly leading to code-switching, but at least promoting lexical borrowing from English and Samoan as evidenced in the data (cf. Section 5 below). An important precondition for such processes was the shared environment and shared daily experiences (that were quite different from life in Germany) and the existence of a small and close-knit community. A contact variety of German indicated in-group membership and marked the border against (German) non-members, in this case: native speakers of German in Germany. The specific social structure of the speech community thus promoted the development of a Samoan variant of German, while, at the same time, the emergence of a characteristic means of communication helped members to identify more strongly with this community.

\subsection{Methods and terminology}

The linguistic analyses applied here are qualitative rather than quantitative (due to the amount and character of the data). In order to get the maximum of infor-

\footnotetext{
${ }^{4}$ Language attrition refers to the loss of language skills in healthy speakers; this may be due to reduced use, to language contact, or to other factors; cf. Schmid and Mehotcheva (2012) on L2 attrition, and Schmid (2013) for an overview on L1 attrition.
}

${ }^{5}$ Cf. Green (1986, 1998), Grosjean (2001, 2013). 
mation out of the data (in the sense of "making the best use of bad [i.e. fragmentary] data", Labov 1994: 11), metalinguistic and linguistic information is used to complement each other and is compared to arrive at a better understanding of the linguistic processes.

With respect to terminology, it should be noted that the definition of and distinction between borrowing and loan(word) varies between different researchers. ${ }^{6}$ It is not possible to safely tell low-frequency borrowings apart from spontaneous interference for Samoan German as many Germans had a fair command of English and could import English items on the spot. While a distinction between spontaneous borrowings vs. established loanwords could have helped to come to a clearer conclusion as to the status of Samoan German, the data turned out not to be sufficiently informative in this regard. To some degree, then, it has to remain open whether Samoan German should be considered a developing local settler variety (with conventionalized loans), or whether it was German as spoken by German-English bilinguals with a spontaneous admixture from English lexical items.

\section{Database}

The analyses are based on linguistic and metalinguistic evidence from different sources. Investigated data sources are:

(a) early 20th century travellers' and settlers' reports (published);

(b) the Samoanische Zeitung (SamZ) ('Samoan newspaper');

(c) archive materials.

\subsection{Published accounts}

During and shortly after the German colonial rule in Samoa, a number of publications appeared describing different aspects of (colonial) life in Samoa. Besides scientific publications, a number of travel reports, published diaries and

\footnotetext{
${ }^{6}$ Cf., e.g., Auer (1999) for a scalar presentation of different types of bilingual language interaction patterns, and Myers-Scotton $(1993,2002,2006)$ for the distinction between borrowing (as an established phenomenon) and code-switching (as a spontaneously produced bilingual item). A terminological overview and discussion is provided by Haspelmath (2009: 40-42).
} 
publications treating ethnographic, sociological, and economic topics appeared. ${ }^{7}$ They often include information about language use between and among different speech communities in Samoa. Examples of object language are sometimes provided for illustration.

Travel reports and diaries were usually published after the authors returned to Germany. Many of these publications aimed at satisfying the exotic and adventurous interests of their readers and, therefore, may not draw an objectively accurate picture at all times. Their accounts can be subjective for several reasons: They want to please, and sometimes influence, their readers; they provide a description of colonial Samoa from a German expatriate point of view (excluding, by nature, settings and contexts to which this social group had no access); and in some cases, they seem to intend to influence their readers morally and/or politically (e.g., Zieschank 1918; cf. Bade 2011).

With these caveats in mind, information about language and language use in German colonial Samoa can be derived from such publications. The reports complement other sources and provide data that are not available elsewhere.

\subsubsection{The Samoanische Zeitung}

The SamZ was published in Apia, Samoa, between 1901-1914. Its main and major part was written in German, with a smaller part in English, summarizing the German articles' content (cf. Riese 2012). From August 1914 (after the takeover of Samoa by New Zealand) the main language of the $\operatorname{SamZ}$ became English (with a German supplement). It was continued until mid-1916 but from early 1915 under a new title, The Samoa Times (Riese 2012: 167; Scheurmann 1935: 21).

Selected issues and texts from the $\operatorname{Sam} Z$ were analyzed, in particular the letters to the editor. ${ }^{8}$ This focus was chosen in order to draw on a broad and varied group of speakers/writers whose language could be investigated. While by far not all articles deal with a language related topic, comments on language use re-

\footnotetext{
${ }^{7}$ A broad range of such publications make up the special collection of the Deutsche Kolonialbibliothek (German Colonial Library), located at the university library of the Goethe-University of Frankfurt/Main, Germany (cf. Huber and Velupillai 2011, 2012). Many thanks go to Magnus Huber (University of Gießen) and his team for drawing my attention to this source and for providing me with relevant excerpts from a number of these publications.

${ }^{8}$ Besides the (main) editor, Emil Lübke, one or two co-editors were employed with the $S a m Z$ for a longer period; they were assisted by a small number of Samoan short-term employees. In addition, several German expatriates contributed regularly to the newspaper (Riese 2012: 168f).
} 
cur. Depending on the subject, borrowings from Samoan and English appear in a number of texts.

\subsubsection{Archive materials}

The National Archives of New Zealand (Wellington) hold government papers from the German colonial period in Samoa, including administrative notes, government announcements, etc.

The personal papers of Wilhelm Solf (1862-1936), council chairman (Munizipalpräsident, 1899) and governor of German Samoa (1900-1911), are stored in the German Bundesarchiv (Koblenz). The files contain a large amount of official and private documents written while Solf held an official position in Samoa.

\subsubsection{A note on printed language data}

Printed sources provide mediated data. In written language production (especially if printed) the writer has considerably more time to (re)draft his/her linguistic product as compared to spoken language. Furthermore, an editing process may have been carried out by others afterwards. Therefore, these data are filtered and do not reflect immediate online productions. On the other hand, contact phenomena appearing in printed productions can be assumed to be conventionalized in the linguistic code since they were not filtered out during the editing process.

The newspaper data show a clear orientation towards standard German language and spelling norms. In earlier issues of the $\operatorname{SamZ}$, there seems to be more tolerance for spelling deviations and idiosyncrasies (Engelberg, p.c.). Letters to the editor generally conform less to standard norms, in spelling as well as in lexical choice and (sometimes) syntax.

5. Findings: Metalinguistic and linguistic evidence for a Samoan German settler variety

In the following section, I present and discuss exemplary findings that give evidence of the use(s) of German in colonial Samoa. The data reflect varying degrees of formality; a factor that can influence the extent of borrowing and inter- 
ference. Thus, different registers are covered, even though the data set is preliminary. The data presented are of the following kind:

\section{Metalinguistic information:}

Sociohistorical background information

Language attitudes expressed in

- travel accounts and diaries

- newspaper articles (SamZ)

\section{Object language data:}

English and Samoan interference in German in

- newspaper articles, letters to the editor $(\operatorname{SamZ})$

- public signs

- unpublished archive materials.

All data are written productions, as explicated in Section 4. In formal contexts, the written norm for standard German can be expected to apply (as these are instances of conceptual literality/language of distance, cf. Koch and Oesterreicher 1985). In less formal registers or those that are considered to be closer to orality and language of immediacy, more interference may occur as the monolingual written norm (of Germany) is observed less strictly. More interference can indicate a closer or less formal relationship with the addressee since it can be understood as a reference to a shared code linked to a shared group membership (cf., e.g., Gumperz 1982; Münch and Stolberg 2003; Myers-Scotton 2006; Poplack 1981).

\subsection{Metalinguistic information}

\subsubsection{Travel accounts and diaries}

Late 19th and early 20th century accounts of travellers and settlers are a valuable source with respect to language behaviour and language use among different speaker groups in the colonized areas of the Pacific. Numerous travel reports and scientific reports on various topics as well as a number of diaries were published during the German colonial period and between the two world wars. Several of these publications focus on Samoa; they provide important information for reconstructing the sociolinguistic setting in which language contact between German, English, and Samoan took place. 


\subsubsection{Metalinguistic information in colonial-time publications}

Several writers comment on the use (and non-use) of German in German Samoa. A recurring topic is the matter of German instruction and the (lack of) use of German as the language of instruction in local schools (government, private, and missionary) (cf. Hiery 2001b; Otto 1989; Stolberg 2012). ${ }^{9}$ Kurze (1900: 87) reports that in the theological college of the LMS at Malua (Upolu) the languages of instruction are Samoan and, in the upper grades, English, the latter being met with great interest (cf. also Berger 1923: 117). A couple of years later, Hesse-Wartegg (1902: 217) notes that in Apia (Upolu) Roman Catholic priests of the French Society of Mary (i.e., Marists) had been the first to teach German, but that the LMS as well as the Wesleyan Methodist mission by then had started to teach German as well. Hassert (1903: 74 fn. 1) highlights the existence of a German school in Apia (founded in 1888 and co-financed by the German government), with 50 German students of a total of 70 (Hassert 1903: 74 fn. 1). Zieschank (1918: 60-61) notes, however, that instruction in and of German is hindered by the fact that children who speak German and those who do not are schooled together, resulting in an unsatisfactory learning progress for all of them. Fiedler (1906: 6), in contrast, considers German instruction (and other European-centered educational contents) rather useless because a satisfactory speaking competence in German is not achieved, he claims.

Statistical information is provided by official government publications (StJbDR 1911; DKAJb 1905) and, focussing on schooling, by a questionnairebased school report for the German colonial areas (Schlunk 1914). Table 1 shows that school attendance was considerably higher for Samoa than for the other German colonial areas in the Pacific, notwithstanding its apparently low impact on the acquisition of (L2) German (cf. Stolberg 2012).

Table 1. School attendance in Samoa (compiled from Schlunk 1914; StJbDR 1911: 44ff., 48ff.; DKAJb 1905:18f.).

\begin{tabular}{lccc}
\hline & Indigenous population & students & School attendance \\
\hline Pacific colonial areas (total) & c. 617,500 & 19,315 & $3.1 \%$ \\
Samoa & c. 33,500 & 9,878 & $29.5 \%$ \\
\hline
\end{tabular}

\footnotetext{
${ }^{9}$ In German Samoa, there were 338 mission schools and two private schools (one German school, one English school). According to Otto (1989: 83), up to 12\% (i.e., approx. 1,000) of all students received German instruction.
} 
Hesse-Wartegg (1902: 217) provides a description of the colonial-linguistic set-up of Apia. Apia's eastern part was dominated by the English speaking expatriate population while the western half was predominantly German. He estimates that about half of the expatriate population of Apia at the time was German (i.e., about 300 - mainly male - German inhabitants, by his account). Hesse-Wartegg, like several other writers, complains about the lack of German (-speaking) women among the colonists, a fact that allegedly led to the decreasing use of German within German-English or German-Samoan mixed-marriage families (Hesse-Wartegg 1902: 217-218; Zieschank 1918: 103 speaks of a dozen or fewer German women in Samoa in 1906, with an increase to about 100 in 1914).

Regarding the actual use of German, Berger (1923: 13, 37, 72, 144; 1932: $11,41)$ reports that he met Samoans as well as so-called "half-casts" (of Samoan-European descent) who spoke German well; they also had a very good command of English, as Scheurmann (1935: 22) points out. Berger's anecdotal account of an older German settler who claimed to soliloquize in German when he had no German-speaking company may be an idiosyncratic instance of patriotism and is probably not generalizable (Berger 1923: 49). Flaherty (1932: 59) who visited Samoa during the 1920s notes that some younger Samoans knew German and attributes this to German-time missionary schools.

The general impression one receives from these reports is that German was used interculturally but English was the more common and more widespread language of communication, among the European expatriates as well as between Europeans and Samoans. It can thus be concluded that also Germans needed to have a fair command of English in order to successfully carry out their everyday interactions.

\subsubsection{The Samoanische Zeitung ('Samoan newspaper’)}

The SamZ recurrently covers language related topics. Notably three articles discuss the use of and attitudes towards the German language in Samoa in detail; several other texts comment on this issue in passing. In addition, a metalinguistic comment on the command of English by Germans is provided by an article on the German-Australian trading statistics for 1901; included is a list of various trade goods in English. Following the list, it is noted that

"[w]ir haben die englischen Namen der Waaren beibehalten, da wir annehmen, dass unsern Lesern dieselben gelaeufig sind und einzelne 
der selben sich nur schwer in deutsch uebersetzen lassen, oder mindestens eine Umschreibung erfordern.

(SamZ, 26 Dec 1914: 10)

[[w]e have left the English names of the goods untranslated since we assume that our readers are familiar with them and since some of them are difficult to translate or at least would require a paraphrase.] (my translation, DS)

This statement makes clear that an adequate command of English is taken for granted with respect to the German readers involved in trading, if not for all German expatriates in Samoa.

The three most explicit texts regarding topics of German colonial language use are now presented in more detail.

(i) The writer of the 1911 article (SamZ, 8 Jul 1911: 1-2) appeals strongly to German national feelings by emphasizing that Samoa, as a German colony, should become more German. In his opinion, the use of German has increased (since 1900), but not sufficiently so. He identifies six different categories of (potential) German language users: Administration and government; settlers; schools; Samoans; German fathers; and every German (viz. in Samoa) (p.1; cf. (a-f) below). The writer describes various settings of language use and language competence. The main points of his report (and appeal) highlight important language contact scenarios. (Translations are mine, DS).

(a) administration, government

Even though the official languages of the administration are Samoan and German, English is allegedly used more frequently than German in all administrative interactions, even in the case of a poor command of English. Also, not all members of the government staff know German.

(b) Settlers

(German) settlers use English wherever possible. The writer describes the language competence of some of the settlers as "[die] paar manchmal ganz schauderhaft ausgesprochenen englischen Brocken" ('[the] few, sometimes quite dreadfully pronounced English chunks') (SamZ, July 8, 1911: 1) but adds that it is hard to get by in (colonial) Samoa without English. 
(c) schools

The writer emphasizes "die vorzüglichen Erfolge der hiesigen deutschen Schulen" [the great success of the local German schools] (SamZ, 8 Jul 1911: 1) in teaching German. German was a subject and in some cases also the medium of school instruction. Reliable and comprehensive reports on the command of German by non-native speakers are hard to find, however, and do not suffice to substantiate or refute the writer's opinion. Possibly his remark is politically motivated, rather than being grounded in language-pedagogical findings.

(d) Samoans

According to the writer, young Samoans who started to learn German in school are in danger of losing their competence because they hardly find the opportunity to apply their knowledge. This warning against imminent L2 attrition implies that speaking German is not a widespread habit in Samoa.

(e) German fathers

The writer speaks of "Dutzende von traurigen Fällen, in denen halbweisse und leider auch weisse Kinder von deutschen Vätern nur englisch, oder doch besser englisch als deutsch sprechen [dozens of sad cases where half-white and unfortunately also white children of German fathers only speak English, or at least better English than German] (SamZ, 8 Jul 1911: 1). He claims that the German(-speaking) fathers of these children do not fulfill their obligation of speaking German within their families (cf. Scheurmann 1935: 22; Zieschank 1918: 57 for similar remarks).

Note that generally it is not uncommon that in a linguistically mixed marriage the language of the environment is chosen as the family language. Thus, the fact in itself is not remarkable. From the perspective of a nation trying to gain a cultural and linguistic foothold in a colonized area, this language behavior is undesirable, though, because it is felt to be a threat to its colonial claims.

(f) every German (in Samoa)

In conclusion, the writer calls on all Germans in Samoa to use German as much as possible to fight off the perceived threat from English, claiming that "wenn jeder Deutsche deutsch spricht, wo und wann er nur irgend kann, wenigstens aber nicht englisch, denn nur von dem 
Englischen droht uns hier Gefahr" [if every German speaks German wherever and whenever possible, but at least not English because only from English are we threatened] (SamZ, 8 Jul 1911: 2), Samoa will become more German than it is at the time of his writing.

In sum, the writer's explicit stance is that the use of German should increase considerably, and that it is the responsibility of all (native) speakers of German to work towards that goal. An important implicit point is that English enjoys a higher prestige than German with all European-origin expatriates, Germans included. It also has a greater currency, so that using English generally guaranteed a successful interaction, while this was not the case for German.

The writer constructs an opposition between English and German based on the contemporary shared knowledge of the specific political and colonial situation. Quite explicitly he links this opposition to language competence when he remarks: "Oder glaubt vielleicht irgend jemand, dass einer, der einer anderen Kultursprache, nicht aber der deutschen mächtig ist, jemals innerlich deutsch fühlen wird und kann? Das ist ganz ausgeschlossen, wenigstens wenn diese andere Kultursprache die englische ist." (SamZ, 8 Jul 1911: 1) [my emphasis, DS] ['Or does possibly anyone at all believe that somebody who, though competent in another culture language, but not in German, will ever feel and be able to feel thoroughly German? This is completely impossible, at least if this other culture language is English.]

(ii) The primary topic of the article in the SamZ, of 26 Jul 1913 (p. 1) is PidginEnglisch 'Pidgin English'. Here, not only the use of English and Pidgin English (in Samoa) is discussed but also the status of German. This piece deals with the subject of a specific Samoan variant of German. The criticism here is about using "degraded German", that is, a variant of German that is perceived to display heavy lexical interference from English.

The writer describes Samoan German as "ein im Vaterlande unverständliches Kauderwelsch [...], das an Lächerlichkeit dem berüchtigten Amerikanerdeutsch ${ }^{10}$ nicht viel nachgiebt" [a gibberish that is unintelligible in the

\footnotetext{
${ }^{10}$ As the author of the quote does not specify what variety he is referring to by Amerikanerdeutsch, any assumptions in this respect must remain hypothetical. At the time of his writing, there existed a body of print literature in American German, i.e. German as used in the USA, exhibiting a noticeable influence from English in spelling and vocabulary (e.g. Pennsylvania German) as well as German regionalisms and instances of language of immediacy, thus deviating from the norms of writ-
} 
homeland [i.e. Germany], and that ranks close to the notorious Americans' German in its ridiculousness] (SamZ, 26 Jul 1913: 1). Criticizing the allegedly extensive amount of borrowing from English, and in line with the writer of the 1911 article, this writer considers it "die Pflicht eines jeden Deutschen, [...] ein reines, gutes Deutsch zu pflegen" [the obligation of each German [...] to maintain a pure and good German] (SamZ, 26 Jul 1913: 1).

In contrast to English, Samoan was obviously not seen as a (linguistic) threat to German, even though Samoan loanwords do appear in contemporary documents and may have contributed to the alleged incomprehensibility of Samoan German in the home country.

(iii) A follow-up article to the previous one, in the SamZ issue of 23 Aug 1913 (p. 1-2), takes up the topic of Pidgin English and the relationship between the two colonial languages, English and German, with respect to Cameroon. From a government order for Cameroon regarding the use of Pidgin English (reproduced as part of the text), the writer concludes that "[n]ach dem Inhalt dieser Verordnung scheint es in Kamerun mit der Sprachverderbnis und dem Verhaeltnis des Deutschen zum Englischen allerdings viel schlimmer zu stehen, als in dem in dieser Beziehung sonst so verrufenen Samoa" [according to the contents of this order it appears that the language corruption and the relationship between German and English are considerably worse in Cameroon than in Samoa which is notorious in this respect] (SamZ, 23 Aug 1913: 2).

The conclusion the writer draws is the same as for Samoan German and comes in almost the same words: "Hiernach scheint sich ein KamerunDeutsch zu entwickeln, das bald dem beruechtigten Deutsch Nordamerikas an Verbastadierung [sic] und Laecherlichkeit nichts nachgeben wird" [According to this, a Cameroon German seems to develop that soon will equal the notorious German of North America in its bastardization and ridiculousness] (SamZ, 23 Aug 1913: 2).

All three texts under discussion bring up similar points of colonial languageideological thought:

- language politics/linguistic nationalism: language and nation are closely linked; the use of a specific language indicates a form of political support for the corresponding (colonizing) nation; 
- language purism: German should be kept pure, and mixing/lexical borrowing (especially from English) should be avoided;

- language choice: language use, it is implied, results from a conscious choice by each individual speaker. In the concrete context of German in Samoa, every native speaker of German is called upon to make the decision to use "pure" German and thus to contribute to its spread.

The following section investigates whether these claims are borne out in the available object language data.

\subsection{Object language data}

Various forms of contact-induced interference are reflected in the object language data. They range from a clear separation of languages to language mixing at the clause level approaching the stage of a fused lect (cf. Auer 1999). Borrowing of content words is the most prevalent type of interference. This type is presented first, followed by the more "extreme" cases of contact phenomena.

\section{(a) Borrowings}

Language contact phenomena in the investigated sources include: (i) overt lexical borrowing from English; (ii) covert influence from English (calques, word order, orthography); and (iii) overt lexical borrowing from Samoan. Overt borrowings can be flagged or unflagged, that is, they may be marked as borrowings by using quotation marks or adding metalinguistic comments or translations into German (cf. Klintborg 1996). Such marking is not consistent, so that the same item may be flagged in one text and not flagged in another. Sometimes borrowings are flagged at their first use in a text but not thereafter. Notably, not all borrowings are comprehensible without previous knowledge of English or Samoan. Nevertheless, translations are not provided very often. This fact in itself points towards a "pool" of (more or less) conventionalized non-German lexical items that were in use among the Samoan German speech community.

(i) English borrowings that appear repeatedly in different sources, and thus seem to be conventionalized to some degree, include: Beach, Creek, Halfcasts, last not least, Meeting, Natives, Store(s); and the mixed 
items Nativehaeuser 'natives' houses' (referring to traditional Samoan thatched-roof houses with open sides) and Schweinefenz 'pig fence'. In total, more than thirty different lexical items and phrases from English appear in the Samoan German sources.

Nouns borrowed from English are usually capitalized, that is, orthographically (partly) integrated. They are morphologically integrated by the use of a determiner encoding gender, number, and case. The only suffix used with English borrowed nouns is the plural marker, usually the plural suffix $-s .{ }^{11}$ There is only one instance (a humorous poem) where the German plural suffix $-e$ is used with an English borrowing (Accidente 'accidents'; SamZ, 30 Dec 1903). ${ }^{12}$ Verbs borrowed from English are rare in the Samoan German sources. If they show up, they are morphologically integrated into German, as finite as well as nonfinite verb forms, for example: geboycottet 'boycotted' (non-finite); pullst $d u$ '(if) you pull' (finite).

(ii) Covert influence from English is much more limited. Very occasionally, word order is affected, showing (English) SVO instead of (German) $\mathrm{V} 2,{ }^{13}$ but not consistently so, even within one text. Regarding orthography, non-established compounds are repeatedly spelled as separate nonhyphenated words, rather than being conjoined or hyphenated. This may be due to influence from English. Loan translations are restricted to a few discourse markers, that is, to elements that tend to be replaced fairly easily in English-German language contact, possibly because of their loose syntactic integration into a clause (cf. Boas and Weilbacher 2009; Fuller 2001; Münch and Stolberg 2005). Relevant items are sage 'say; for example' (G sagen wir (mal) [coll.] 'say'); eben 'even' (G sogar 'even'); in meiner Meinung 'in my opinion' (G meiner Meinung nach 'in my opinion'). Sage is used repeatedly and by several writers while the other two items seem to be isolated uses. Still, their appear-

\footnotetext{
${ }^{11}-s$ as a plural suffix is a plural marker in German as well as in English. Thus, it could be a morphological transfer from English or a German morphological marking.

${ }^{12}$ Accidens/Accident, as a borrowing from Latin, French, and/or English, is testified in German much earlier (e.g. in the Goethe-Wörterbuch (vol. 1, 1978) for as early as 1783). What is noteworthy here is the German plural morphology that is not commonly attested for this loanword.

${ }^{13}$ The difference becomes visible with, e.g., topicalizations where in English SVO is maintained

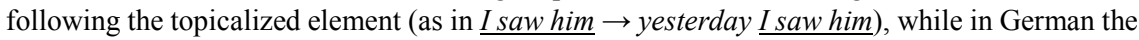
inflected verb remains in second position (ich sah $i h n \rightarrow$ gestern sah ich ihn, lit. 'yesterday saw I him').
} 
ance in print indicates that they were licensed by the respective speaker/writer and considered appropriate in a (written) German context.

(iii) While English borrowings come from various semantic fields, Samoan borrowings are mainly restricted to titles, administrative terms, and lexical items referring to specifically Samoan objects and activities; almost all of them are nouns. Examples are: lava-lava (a traditional item of clothing), leoleo 'police', faa samoa 'in the Samoan way', faletele 'assembly house', fautasi (a longboat for a traditional ship race), fitafita '(member of the) police or national guard', fono 'council', papalagi 'European-origin foreigner', siva (a traditional Samoan dance), taupou (a ceremonial hostess in a Samoan village, usually from a high-ranking family). Occasionally, articles in the SamZ provide lists with and explanations of Samoan titles, or Samoan names of local games, food, animals, and plants. Aside from such lists, more than twenty different Samoan lexical items and phrases were identified in the Samoan German sources.

In general, Samoan borrowings are neither orthographically (by capitalization) nor morphologically integrated, except for an occasional plural marking with the suffix $-s$ (e.g. matai 'leader, head' [a Samoan title] sg. - matais pl., NANZ-044; fitafita sg. - fitafitas pl., SamZ, 7 Dec 1901: 2). ${ }^{14}$

(b) Variance in borrowing

While the amount of written data alone justifies the investigation of German in Samoa, spoken data would contribute to a more complete picture but could not be found yet. A rare instance of datum allowing an impression of the differentiation between oral vs. written language use was found in the papers of Wilhelm Solf at the German Bundesarchiv.

Among these documents, there is a protocol Solf took down to record an apparently heated oral dispute with commander Emsmann ${ }^{15}$ regarding the colonial government's treatment of the local population (Solf 1899). In this protocol, a small number of Samoan and English borrowings are used (e.g., Taitaifono

\footnotetext{
${ }^{14}$ Plurals in Samoan are built in completely different ways (cf., e.g., Mosel and So'o 1997), i.e. the plural marker $-s$ was not transferred from Samoan.

${ }^{15}$ Hugo Emsmann (1858-1933) was commander of the light cruiser SMS Cormoran that was docked in the harbour of Apia from January 1899 to November 1900.
} 
'council chairman', Malietoa ${ }^{16}$-Chiefs, Natives). This is noteworthy since Solf, who reportedly was a fluent speaker of English and Samoan, hardly ever uses any borrowings in other written documents. In particular, the English borrowing Natives appears in the 1899 protocol while Solf opts for the corresponding German term Eingeborene in all other official writings investigated.

The borrowing Natives appears repeatedly in different texts in the SamZ, that is, in a genre marked by a less formal and official writing style than most governmental documents. A possible interpretation of the variation in Solf's writings is that Natives is the more oral and less official variant used in Samoan German while Eingeborene was the official German term to refer to the local colonized population. The heatedness of the protocolled interaction may have contributed to a less formal word choice. The difference in the use of borrowings in Solf's papers points towards a differentiation between spoken and written, or colloquial and formal, German in Samoa.

An additional aspect of the concept of (socio)linguistic setting is the role of the addressee for a speaker's choices on language mixing. In the protocolled discussion, as well as for the SamZ texts, the addressees are familiar with Samoan German and the setting of colonial German Samoa. In general, then, English and Samoan borrowings could be presumed to be comprehensible. In contrast, such competence could not be taken for granted when the addressee was a government official in Germany. Solf, being highly educated and familiar with German governmental language usage, is likely to have chosen in his official writings a formal German of the kind that was considered appropriate for the German government of the time.

In sum, social group membership (graded between distance and proximity, and in-group and out-group membership), the relationship between speaker/writer and addressee (graded between distance and proximity, and formality and informality), and the medium of communication (graded between conceptual literality and conceptual orality) are the most relevant factors to be taken into account when interpreting the variance in the use of borrowings in Samoan German texts.

(c) Official language use: Public signs

Official signs in colonial German Samoa were an expression of language choice and language prestige, indicating what language was considered appropriate for official and legal orders. Two contrasting reports represent different positions.

${ }^{16}$ Malietoa is the title of a special group of high ranking traditional governors of Samoa. 
Zieschank (1918: 43) describes how she and her (expatriate) company came across a public sign in German rather unexpectedly:

Ungefähr eine halbe Stunde vom Ziele entfernt, sahen wir uns mitten im Urwalde vor einer Gesetzestafel stehen: „,Weiter hinauf dürfen keine Pferde mitgeführt werden, Zuwiderhandlungen werden mit 20 Mark Geldstrafe gebüßt.“

[About half an hour away from our destination, we encountered a legal sign in the middle of the jungle: "No horses are allowed to be taken further up. Violations are punished with a penalty of 20 marks."]

Zieschank considered this a very unusual place for an order sign in German, as she makes clear by her conceptually contrasting word choice (Urwald 'jungle, virgin forest' vs. Gesetzestafel 'legal sign ${ }^{17}$ ) and a comment on the incident. She indicates that this use of German is inappropriate in the colonial situation implying that German, although formally the language of government, has only a limited applicability outside the "civilized", that is, colonially imprinted, environment of Apia.

A contrasting evaluation of a similar setting is reported in an article of the SamZ of 30 Apr 1910 (p. 1):

Nicht weit von Apia stiessen wir an Zweigwegen auf verschiedene Tafeln, welche die Aufschrift trugen: „No Admittance“ und in samoanischer Uebersetzung etwa Folgendes: „Ua sa le ala nei“. Ein deutsches Wort hierfuer scheint der Besitzerin, einer deutschen Firma[,] unbekannt zu sein.

[Not far from Apia, we encountered several signs at some branchingoff paths, bearing the inscription: "No Admittance" and in Samoan translation roughly: "Ua sa le ala nei". A German word for this seems to be unknown to the owner, a German firm.]

Here, the language choices that make most sense from a practical point of view (potential addressees, language(s) of widest currency) are criticized. By pointing out that the owner of the area is a German firm, two claims are made: firstly, German language competence is available; secondly, choosing English and Samoan for the signs indicates either a conscious decision against German, or linguistic inability contrary to expectation (the latter with a provocative touch).

\footnotetext{
${ }^{17}$ The German noun Gesetzestafel (lit. 'law table') also faintly alludes to the biblical Tables of the Law, making the contrast even more marked.
} 
The two contrasting perspectives reflect different attitudes towards the use of German in formal contexts. While Zieschank explicitly criticizes English borrowings in Samoan German, she sees German as linked to the expatriate German speech (and cultural) community. A clearly different position is taken by the $\operatorname{SamZ}$ article writer who indicates that German is applicable in all settings, symbolizing the exertion of German colonial control in Samoa.

(d) Language mixing

Two letters to the editor of the $\operatorname{SamZ}$ (21 Dec 1901: 3; 18 Jan 1902) contain an exceeding number of English borrowings, strikingly deviating from general Samoan German usage. All borrowings are integrated orthographically and follow the lines of a German pronunciation of English sounds (e.g. sohld 'sold' for German verkauft 'sold').

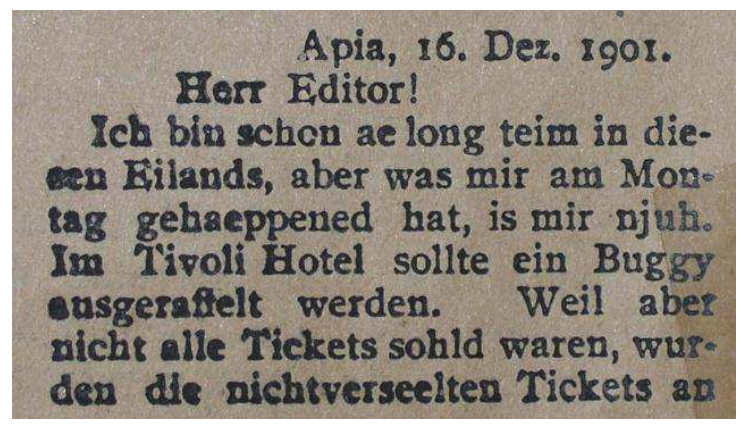

Figure 1. Section from a letter to the editor

(Samoanische Zeitung, 21 Dec 1901: 3).

A linguistic analysis shows that interference from English is mainly restricted to borrowed content words (nouns, verbs, adjectives, some adverbial phrases). German syntactic structures and word order are completely in place. There is one instance of a calqued sentence structure: [d] ie heihest Nummer dachte das Buggy gewonnen zu haben 'the highest number thought to have won the buggy' (dachte 'think $\mathrm{PAST}_{\mathrm{P}}+$ infinitival complement) ${ }^{18}$; aside from that, there is no inter-

\footnotetext{
${ }^{18}$ Usually, denken 'think' is used either with a dass-clause (that-clause) or with an embedded V2 clause in German. Note that, in the example, the word order within the infinitival complement (das
} 
ference from English with regard to word order where English and German would differ. German derivational and inflectional morphology is applied to English nouns and verb stems (e.g. die Frontwiehls 'DET front wheel+PL', cf. G die Vorderräder 'the front wheels'; verauktioniehrte 'VER+auctioneer+PAST', cf. $\mathrm{G}$ versteigerte 'auctioneered').

Against the backdrop of repeated concerns about the (allegedly corrupted) state of German in Samoa, these texts could be intended as a mock version of Anglicized German as spoken in colonial German Samoa to prove the point. Notably, both letters are signed with names that are likely to be fictitious ( $D o b$ beljuh Schuhflicker 'double-u shoe fixer'; Mr. Suarzsour 'Mr. Blacksour').

It is, of course, conceivable that Samoan German in its spoken variant indeed looked like the variety used in these letters. Taking into account the great difference between these two and all other texts, however, I consider it more likely that these texts were produced to give a daunting example of "corrupted" Samoan German in order to support an argument for language purism.

\subsubsection{General observations}

\subsubsection{Visual impression}

In the $S a m Z$, umlauts are generally printed as digraphs ( $a$ e for $\ddot{a}$, oe for $\ddot{o}, u e$ for $\ddot{u})$, probably for technical reasons. For someone in, or a recent arrival from, Germany, this was unfamiliar, and, in combination with lexical borrowings not known in Germany, contributed to a notion of foreignness.

The components of compound nouns are often non-conjoined, in contrast to common German usage but similar to English. Besides that, there are no orthographic features attributable to influence from English.

\subsubsection{Structural features}

The Samoan German data do not exhibit structural deviances of a systematic kind. There are rare occasions of word order deviation (SVO instead of the required V2, cf. above and fn. 13), but these are restricted to one single writer. Thus, this could be a case of individual L1 (German) attrition in a long-term L2 (English) environment.

Buggy gewonnen zu haben 'to have won the buggy') follows German verb-final clause structure, not English V-O order. 


\subsubsection{Lexicon}

In general, the analyzed data do not contain large numbers of borrowings, either from English or Samoan. In addition, most borrowings are nouns, usually the most frequently presented category of lexical borrowings. ${ }^{19}$ This finding contrasts with reports about strong English influence on German that allegedly parallels English interference in North American German. In all but two Samoan German documents, only a small number of borrowed lexemes is used repeatedly and by different writers. These borrowings often appear without a German translation or any other kind of flagging, indicating that they were conventionalized loanwords for the contemporary Samoan German speech community.

In sum, the types of linguistic interference found in Samoan German can be categorized as follows:

(1) Overt lexical borrowing ${ }^{20}$

(a) non-integrated and flagged (Samoan and English items)

Flagging can be done by translation into German or by typescript marking, for example, the use of quotation marks or italics; these items are marked as foreign imports.

Examples:

- Samoan: das bunte "Lavalava" "the colorful lavalava [Samoan piece of clothing]' (Scheurmann 1935: 5);

- English: eine der "attractions" "one of the attractions" (SamZ, 13 Apr 1912: 2).

(b) non-integrated, not flagged (Samoan and English items)

Such lexical items are not particularly marked but are recognizable as foreign elements; they are not integrated by use of morphological markers.

Examples:

- Samoan: aus dessen Rinde der siapo gemacht wird 'from the bark of which [the] siapo is made' (SamZ, 27 Apr 1912);

- English: plenty Regen 'a lot of rain' (SamZ, 20 Dec 1903: 4).

\footnotetext{
${ }^{19}$ Tadmor (2009: 61); cf. Haspelmath (2009); Thomason (2001); Thomason and Kaufman (1988).

${ }^{20}$ In the examples, quotation marks appear as in the original; the underlining of borrowed items is mine, DS.
} 
(c) integrated (morphologically, orthographically) (mainly English items) An integration of this kind indicates that the borrowings are not perceived to be disruptive elements within the local German variety.

Examples:

- Samoan: Jahresfest der Fitafitas 'one-year celebration of the fitafitas [members of the local police]' (SamZ, 7 Dec 1901: 2)

- English: pullst du und gewinnst nicht [...] 'if you pull and don't win [...]' (SamZ, 3 Aug 1912)

(2) Covert lexical/semantic borrowing (precursors of semantic change), that is, structural borrowing within the lexicon (cf. Haspelmath 2009).

(3) Structural borrowing (word order); only attested in single cases.

In the following section I discuss whether Samoan German can be considered a new variety of German or whether these observations fall under "the inherent variability characteristic of spontaneous speech" (Poplack and Levey 2010: 410 ), only transferred into writing. The latter case would not justify referring to Samoan German as a distinct variety from a linguistic point of view.

\section{Discussion}

Metalinguistic data referring to German in colonial Samoa give the impression that changes in the local use of German are taking place and have taken place, culminating in the claim that Samoan German is no longer comprehensible in Germany (SamZ, 26 Jul 1913: 1). The alleged changes are evaluated negatively. Language behavior is criticized (too little use of German, preference for English and Pidgin English). Notably, interference from Samoan is neither criticized nor even mentioned explicitly.

A closer investigation showed that object language data do not corroborate the metalinguistic assumption of extensive interference from English (or Samoan). Lexical borrowings from both languages occur to a rather limited degree and are restricted to content words. Where the content focuses on administrative matters referred to by Samoan terms, however, comprehensibility is reduced for someone unfamiliar with the colonial German-Samoan setting (e.g., NANZ044, NANZ-045).

(The lack of) flagging in lexical borrowings can be an indicator for a borrowing's status in this respect. A systematic use of flagging (of any kind) could 
not be established beyond each individual text. In general, flagging is more frequent in texts that refer to (meta)linguistic topics while texts that do not focus on language (use) tend not to flag borrowings, either English or Samoan. Samoan borrowings are more often translated at first use (within a text) than English borrowings; but there are also numerous cases where Samoan items are not flagged in any way, indicating that they are conventionalized.

Regarding the distinction between loanword and single-word code-switches, Haspelmath (2009: 40) remarks that "[...] a loanword [...] can be used in situations where no code-switching occurs, e.g. in the speech of monolinguals. This is the simplest and most reliable criterion for distinguishing loanwords from single-word switches".

In this sense, Samoan borrowings should be considered loanwords in Samoan German since the majority of expatriates did not speak Samoan. Despite this status assessment, Samoan borrowings often are less integrated than English borrowings, that is, they remain more salient as foreign elements. Codeswitching between German and Samoan (by native speakers of German) is highly unlikely to have occurred in any large measure, so borrowings from Samoan can certainly not be derived from code-switching processes. A number of the English borrowings, on the other hand, could indeed be single-word switches, even though their occurrence in print indicates a certain degree of conventionalization.

Overall, no indications of a more profound language change (e.g., in the sense of the hierarchies presented in Thomason and Kaufman 1988 and Thomason 2001) were found in the analyzed data. Structural interference is rare; some semantic interference seems to have taken place, but word order and morphology are largely unaffected. In rare instances, case endings are deviant. This is not systematic, therefore an interpretation as typographical errors, rather than contact-induced interference, is conceivable.

A desideratum of many historical-linguistic investigations is (conceptually) oral data, and the current study is no exception. Since the production of written/ printed data is likely to be more consciously controlled, the view on the variety under investigation is restricted. This can be compensated to some degree by using written data from as many different contexts and registers as possible, thus approaching a more differentiated picture. Unpublished primary data, close to or recording spoken language registers, would be a valuable addition to the data base; eligible sources could be diaries, private letters, or protocols of oral interactions (e.g. in a court room). Not all private sources are pertinent, though: A cursory investigation of personal letters written by the government official Solf showed that even his non-official letters closely adhere to a normative written 
register (fitting in with the expected writing behavior of higher social/educational classes, cf. Elspaß 2005).

In conclusion, the data imply the beginning emergence of a settler variety in German Samoa, with lexical interference from English and Samoan and little structural interference from English. Linguistically, this development does not justify treating Samoan German as a separate German variety, especially since after the end of the German colonial rule in Samoa the colonial German speech community dissolved and the use of Samoan German was (most likely) discontinued. I venture to hypothesize that, with more time, Samoan German would have developed into a new extraterritorial variant of German, comparable to the linguistic development that took place in Namibia and resulted in today's distinct Namibian (L1) German (cf. Kellermeier-Rehbein 2012; Pütz 1991; Shah 2007).

\section{Conclusions}

The main goal of this paper was to assess the linguistic developments in German reported and documented in contemporary data of colonial German Samoa. This entailed the reconstruction of the sociolinguistic set-up of the German speech community in order to evaluate the data properly.

Samoan German refers to the (first) language of the colonizers; so far, there is no data available from German-speaking (or German-writing) Samoans for that period. German was in contact with English, a co-colonial language, and, to a lesser degree, with Samoan, the primary local language. Communication between Germans and Samoans frequently occurred either in English or with the help of a translator (cf. Zieschank 1918). In contrast to German-English bilingualism, German-Samoan bilingualism was not widespread.

The changed variant of German was evaluated negatively from a normative perspective, for example, by short-term visitors and new arrivals from Germany who were not familiar with it. Such judgements contain also implicit statements about the relationship between language (use) and political power.

In order to put the documented contact outcomes into relation, the pervasive presence of English in Samoa must be taken into account. This presence went far beyond the linguistic realm, as the following quote demonstrates:

Es erscheint ausser Frage, dass bei der Lage Samoas eine Anglisierung des Schutzgebietes dauernd droht. Einer solchen direkt entgegen $\mathrm{zu}$ arbeiten, waere zwecklos und nicht einmal im Interesse des Lan- 
des, da das englische Element einen nicht zu vernachlaessigenden Faktor im hiessigen [sic] Wirschaftsleben spielt.

(SamZ, 10 Oct 1910: 4)

[It seems beyond doubt that, due to the location of Samoa, the Anglicization of the protectorate is a constant threat. To work directly against it [viz. the threat] would be useless and not even in the best interest of the nation because the English element plays a significant role in the local business life.]

While the economic setting differed, the language situation in other areas under German colonial rule was comparable in many places, as the $\operatorname{SamZ}$ article on Cameroon (SamZ, 23 Aug 1913) exemplifies, indicating that the use of German was not widespread, particularly if English and/or Pidgin English had been established as a lingua franca beforehand (cf. Engelberg 2006). One exception stands out: Namibia. Here, the number of German settlers was higher than in any other German colonial area, so that a stable speech community could establish itself, resulting in German still being spoken natively (Namibian German; cf. Pütz 1991; Shah 2007) or as a heritage second language (Namibian Black German; cf. Deumert 2009).

For Namibian (L1) German, Shah (2007: 42) notes that contact-induced interference is most obvious in the lexicon, similar to Samoan German. Both varieties originated in a colonial setting and represent cases of adoptive borrowing (Haspelmath 2009) in a language maintenance setting (Thomason and Kaufman 1988) driven by recipient speaker agentivity (Van Coetsem 1995). For future research, then, it seems promising to compare these two colonial variants of German in order to arrive at a better understanding of this aspect of colonial (-origin) language contact.

\section{REFERENCES}

\section{ARCHIVE MATERIALS}

ABCFM-3. Jenny Olin: Letter to Dr. Judson Smith; Kusaie, Caroline Islands, August 9, 1902. American Board of Commissioners for Foreign Missions Archives. ABC 19.4. Vol. 16, Micronesia Mission 1900-1909, Letters J-P. Houghton Library, Harvard University.

ABCFM-42. Philip A. Delaporte, Salome Delaporte, Maria Linke: Tenth Annual Report of the Nauru Mission, 1911. American Board of Commissioners for Foreign Mis- 
sions Archives. ABC 19.4. Vol. 18, Part 1, Micronesia Mission 1910-1919, Documents Reports Letters. Houghton Library, Harvard University.

NANZ-044. Archives of the German Colonial Administration 1900-1914. Series 2. Secretariat: New Series. XVII-A. Administration of Native Affairs. General. 5. Molestations of foreigners by Samoans. 1. 1903-05. Microfilm 5776-7: 0244. National Archives of New Zealand.

NANZ-045. Archives of the German Colonial Administration 1900-1914. Series 2. Secretariat: New Series. XVII-A. Administration of Native Affairs. General. 5. Molestations of foreigners by Samoans. 1. 1903-05. Microfilm 5776-7: 0275. National Archives of New Zealand.

Solf, W. 1899. Aufzeichnung über eine Unterredung mit dem Kommandanten des "Cormoran" in Gegenwart des Deutschen Konsuls am 24. Decbr. 1899. Papers of Wilhelm Solf, BArch N 1053/19, fol. 1: 68-71. Bundesarchiv Koblenz.

\section{SECONDARY SOURCES}

Auer, P. 1999. "From code-switching via language mixing to fused lects: Toward a dynamic typology of bilingual speech". International Journal of Bilingualism 3(4). 309-332.

Bade, J.N. 2011. Karl Hanssen's Samoan war diaries, August 1914-May 1915. Frankfurt/Main: Peter Lang.

Berger, A. 1923. Talofa: Sturm- und Sonnentage auf Samoa. Dresden: Deutsche Buchwerkstätten.

Berger, A. 1932. Südseemalanga: als Gast der Sonnenkinder auf Samoa. Berlin: Sibyllen-Verlag.

Boas, H.C. and H. Weilbacher. 2009. "The unexpected survival of German discourse markers in Texas German”. CLS 42-1: The Main Session. Papers from the 42nd Annual Meeting of the Chicago Linguistics Society. 1-15.

Boulleys, V.E. 1998. Deutsch in Kamerun. Dr. Rabes Hochschulschriften (vol. 3). Bamberg: Collibri-Verlag.

Deumert, A. 2009. "Namibian Kiche Duits: The making (and decline) of a Neo-African language". Journal of Germanic Linguistics 21(4). 349-417.

Deutscher Kolonialatlas mit Jahrbuch (=DKAJb). 1905. Herausgegeben auf Veranlassung der Deutschen Kolonialgeselschaft. Berlin: Reimer.

Deutsches Reichsgesetzblatt (= DRGBl). 1881. (Vol. 4.) Berlin: Reichsverlagsamt.

DiPaola, K. 2004. Samoa - 'Perle' der deutschen Kolonien? 'Bilder' des exotischen Anderen in Geschichte(n) des 20. Jahrhunderts. (PhD dissertation, University of Maryland.)

Elspaß, S. 2005. "Standardisierung des Deutschen. Ansichten aus der neueren Sprachgeschichte ,von unten“". In: Eichinger, L.M. and W. Kallmeyer (eds.), Standardvariation: Wie viel Variation verträgt die deutsche Sprache? (Institut für Deutsche Sprache, Jahrbuch 2004.) Berlin: Walter de Gruyter. 63-99. 
Engelberg, S. 2006. "The influence of German on the lexicon of Palauan and Kosraean". In: Allen, K. (ed.), Selected papers from the 2005 Conference of the Australian Linguistic Society. <http://www.als.asn.au/proceedings/als2005.html>

Engelberg, S. 2008. "The German language in the south seas: Language contact and the influence of language politics and language attitudes". In: Schulze, M., J.M. Skidmore, D.G. John, G. Liebscher and S. Siebel-Achenbach (eds.), German diasporic experiences: Identity, migration, and loss. Waterloo, ON: Wilfrid Laurier University Press. 317-330.

Engelberg, S. and D. Stolberg. 2012. "German in the Pacific: Language policy and language planning. Governmental and mission activities in the German-colonial era (1884-1914)". Paper presented at the 7th International Conference on Missionary Linguistics, Bremen University, Germany.

Fiedler, H. 1906. Regierung und Nutzbarmachung der samoanischen Inseln. Berlin: Süsserott.

Flaherty, R.J. 1932. Samoa. Berlin: Verlag Reimar Hobbing

Friederici, G. 1911. "Pidgin-Englisch in Deutsch-Neuguinea". Koloniale Rundschau 2. 92-106.

Garrett, J. 1982. To live among the stars. Suva, Fiji: Oceania Printers Ltd.

Goethe-Wörterbuch. 1978. Berlin-Brandenburgische Akademie der Wissenschaften/ Akademie der Wissenschaften der DDR/Deutsche Akademie der Wissenschaften/ H. Reinitzer (ed.). Stuttgart: Kohlhammer.

Green, D.W. 1986. "Control, activation and resource: A framework and a model for the control of speech in bilinguals". Brain and Language 27. 210-223.

Green, D.W. 1998. "Mental control of the bilingual lexico-semantic system". Bilingualism: Language and Cognition 1. 67-81.

Grosjean, F. 2001. "The bilingual's language modes". In: Nicol, J. (ed.), One mind, two languages: Bilingual language processing. Oxford: Blackwell. 1-22.

Grosjean, F. 2013. "Bilingual and monolingual language modes". In: Chapelle, C. (ed.), The encyclopedia of applied linguistics. Hoboken, NJ: Blackwell Publishing. 502510.

Gumperz, J.J. 1982. Discourse strategies. Cambridge: Cambridge University Press.

Haspelmath, M. 2009. "Lexical borrowing: Concepts and issues". In: Haspelmath, M. and U. Tadmor (eds.), Loanwords in the world's languages. A comparative handbook. Berlin: De Gruyter. 35-54.

Hassert, K. 1903. Die neuen deutschen Erwerbungen in der Südsee: die Karolinen, Marianen und Samoa Inseln. Leipzig: Seele

Hesse-Wartegg, E. von. 1902. Samoa, Bismarckarchipel und Neuguinea: drei deutsche Kolonien in der Südsee. Leipzig: Weber

Hiery, H.J. 2001a. "Die deutsche Verwaltung Samoas 1900-1914”. In: Hiery, H.J. (ed.), Die deutsche Südsee 1894-1914. Ein Handbuch. Paderborn: Ferdinand Schöningh. 649-675.

Hiery, H.J. 2001b. "Schule und Ausbildung in der deutschen Südsee”. In: Hiery, H.J. (ed.), Die deutsche Südsee 1894-1914. Ein Handbuch. Paderborn: Ferdinand Schöningh. 198-238. 
Hiery, H.J. (ed.). 2001c. Die deutsche Südsee 1884-1914. Ein Handbuch. Paderborn: Ferdinand Schöningh.

Huber, M. and V. Velupillai. 2011. "German colonial sources and the history of West African Pidgin English. A first analysis of the holdings of the Deutsche Kolonialbibliothek". Paper presented at SPCL, Accra, 2-6 August 2011.

Huber, M. and V. Velupillai. 2012. "German colonial sources and the history of Pidgin English. A first analysis of the material relating to German New Guinea in the Deutsche Kolonialbibliothek". Paper presented at the 7th International Conference on Missionary Linguistics, Bremen, 28 Feb - 2 Mar 2012.

Kellermeier-Rehbein, B. 2012. "Koloniallinguistik aus hochschuldidaktischer Perspektive”. In: Engelberg, S. and D. Stolberg (eds.), Sprachwissenschaft und kolonialzeitlicher Sprachkontakt. Sprachliche Begegnungen und Auseinandersetzungen. (Koloniale und Postkoloniale Linguistik 3.) Berlin: Akademie Verlag. 293-309.

Klintborg, S. 1996. "Linkers, fillers, tags and flags. Code-switching of conjunctions and conversational signals among American Swedes". In: Ureland, P.S. and I.O. Clarkson (eds.), Language contact across the North Atlantic. Proceedings of the working groups held at University College, Galway (Ireland), 29 Aug - 3 Sep 31992 and the University of Göteborg (Sweden), 16-21 Aug 1993. Tübingen: Niemeyer. 199-215.

Koch, P. and W. Oesterreicher. 1985. "Sprache der Nähe - Sprache der Distanz. Mündlichkeit und Schriftlichkeit im Spannungsfeld von Sprachtheorie und Sprachgeschichte". Romanistisches Jahrbuch 36. 15-43.

Kurze, G. 1900. Samoa: das Land, die Leute und die Mission. Berlin: Warneck

Labov, W. 1994. Principles of linguistic change. (Vol. 1: Internal factors.) Oxford: Blackwell.

Macha, J. 2008. "Between the language varieties: Writing behavior of German immigrants to the U.S.”. In: Raab, J. and J. Wirrer (eds.), Die deutsche Präsenz in den USA. The German Presence in the U.S.A. Berlin: LIT Verlag. 723-744.

Mosel, U.L. and A. So'o. 1997. Say it in Samoan. (Pacific Linguistics D-88.) Canberra: The Australian National University.

Mühlhäusler, P. 1979. Growth and structure of the lexicon of New Guinea Pidgin. (Pacific Linguistics C-52.) Canberra: Australian National University.

Mühlhäusler, P. 1984. "Tracing the roots of Pidgin German". Language \& Communication 4(1). 27-57.

Mühlhäusler, P. 2001. "Die deutsche Sprache im Pazifik". In: Hiery, H.J. (ed.), Die deutsche Südsee 1894-1914. Ein Handbuch. Paderborn: Ferdinand Schöningh. 238-262.

Mühlhäusler, P. 2012. "Sprachliche Kontakte in den Missionen auf Deutsch-Neuguinea und die Entstehung eines Pidgin-Deutsch". In: Engelberg, S. and D. Stolberg (eds.), Sprachwissenschaft und kolonialzeitlicher Sprachkontakt. Berlin: Akademie Verlag. 71-100.

Münch, A. and D. Stolberg. 2003. “'Die subway hat uns aa net gfalln’: Markierung sozialer Identität im bilingualen und bikulturellen Kontext". Paper presented at Zum State of the Art der interaktionalen Soziolinguistik. Kolloquium mit John Gumperz und Jenny Cook-Gumperz, Institut für Deutsche Sprache, Mannheim. 
Münch, A. and D. Stolberg. 2005. "Zwei languages zusammenputten: Bilingual ways of expressing bicultural identities”. In: Preisler, B., A. Fabricius, H. Haberland, S. Kjaerbeck and K. Risager (eds.), The consequences of mobility: Linguistic and sociocultural contact zones. Roskilde: Department of Language and Culture, Roskilde University. <http://diggy.ruc.dk:8080/bitstream/1800/8709/1/Munch_Stolberg.pdf> Myers-Scotton, C. 1993. Duelling languages: Grammatical structure in codeswitching. Oxford : Clarendon Press.

Myers-Scotton, C. 2002. Contact linguistics: Bilingual encounters and grammatical outcomes. Oxford: Oxford University Press.

Myers-Scotton, C. 2006. Multiple voices. An introduction to bilingualism. Malden, MA: Blackwell.

Otto, H. 1989. Deutsches Lehngut im Samoanischen und Sprachunterricht auf Samoa. (Unpublished MA thesis, Universität Hamburg.)

Poplack, S. 1981. "Syntactic structure and social function of code-switching”. In: Duran, R. (ed.), Latino language and communicative behavior. New Jersey: Ablex Publishing Corp. 169-184.

Poplack, S. and S. Levey. 2010. “Contact-induced grammatical change”. In: Auer, P. and J.E. Schmidt (eds.), Language and space - An international handbook of linguistic variation. (Vol. 1: Theories and methods.) Berlin: Walter de Gruyter. 391419.

Pütz, M. 1991. “'Südwesterdeutsch' in Namibia: Sprachpolitik, Sprachplanung und Spracherhalt". Linguistische Berichte 136. 455-476.

Riese, J. 2012. "The Samoanische Zeitung (1901-1914): Images of the Samoan people and culture in a German colonial newspaper". In: Engelberg, S. and D. Stolberg (eds.), Sprachwissenschaft und kolonialzeitlicher Sprachkontakt. Berlin: Akademie Verlag. 165-189.

Samoanische Zeitung. 1901-1914. Apia, Samoa.

Scheurmann, E. 1935. Erinnerungen aus der Besetzungszeit Samoas. Korbach: Bing.

Schlunk, M. 1914. Die Schulen für Eingeborene in den deutschen Schutzgebieten am 1. Juni 1911. Hamburg: L. Friederichsen \& Co.

Schmid, M.S. 2013. "First Language Attrition". WIRE's Cognitive Science 4(2). 117 123.

Schmid, M.S. and T.H. Mehotcheva. 2012. "Foreign language attrition”. Dutch Journal of Applied Linguistics 1(1). 102-124.

Sembritzki, E. 1913. "Deutsche Sprache in deutschen Kolonien". Deutsche KolonialPost (Beilage) VIII(11). 128-129.

Shah, S. 2007. "German in a contact situation: The case of Namibian German". eDUSA 2(2). 20-45.

Statistisches Jahrbuch für das Deutsche Reich (= StJbDR). 1911. Berlin: Kaiserliches Statistisches Reichsamt.

Stolberg, D. 2011. "Why German? European encounters in the Pacific". Paper presented at the Conference on Prestige in Language and History: Explorations in 18th- and 19th-century Europe, Helsinki University, Finland. 
Stolberg, D. 2012. "Sprachkontakt in der Schule: Deutschunterricht in Mikronesien (1884-1914)". In: Engelberg, S. and D. Stolberg (eds.), Sprachwissenschaft und kolonialzeitlicher Sprachkontakt. Berlin: Akademie Verlag. 139-162.

Stolberg, D. To appear. Changes between the lines. Diachronic contact phenomena in written Pennsylvania German. Berlin: De Gruyter.

Stolberg, D. To appear. "German in the Pacific: Language policy and language planning”. In: Zimmermann, K. and B. Kellermeier-Rehbein (eds.), Colonial aspects of missionary linguistics. Berlin: Akademie Verlag.

Tadmor, U. 2009. "Loanwords in the world's languages: Findings and results". In: Haspelmath, M. and U. Tadmor (eds.), Loanwords in the world's languages. A comparative handbook. Berlin: Walter de Gruyter. 55-75.

Thomason, S. 2001. Language contact. Edinburgh: Edinburgh University Press

Thomason, S.G. and T. Kaufman. 1988. Language contact, creolization and genetic linguistics. Berkeley: University of California Press

Tryon, D.T. and J.-M. Charpentier. 2004. Pacific pidgins and creoles. Origins, growth and development. Berlin: Walter de Gruyter

Van Coetsem, F. 1995. "Outlining a model of the transmission phenomenon in language contact". Leuvense Bijdragen 84(1). 63-85.

Volker, C. 1991. "The birth and decline of Rabaul Creole German". Language and Linguistics in Melanesia 22. 143-156.

Weinreich, U., W. Labov and M.I. Herzog. 1968. Empirical foundations for a theory of language change. Austin: University of Texas Press.

Wurm, S.A. and P. Mühlhäusler (eds.). 1984. Handbook of Tok Pisin (New Guinea Pidgin). (Pacific Linguistics C-70.) Canberra: Australian National University

Zieschank, F. 1918. Ein Jahrzehnt in Samoa (1906-1916). Leipzig: E. Haberland Verlag.

\section{Address correspondence to:}

Doris Stolberg

Institut für Deutsche Sprache

R 5, 6-13

D-68161 Mannheim

Germany

stolberg@ids-mannheim.de 